\title{
SCID mice model in vivo evaluation of autologous and allogeneic dendritic cells activity on B-cell chronic lymphocytic leukemia
}

\author{
Iwona Hus ${ }^{1 *}$, Jerzy Kawiak ${ }^{3 *}$, Grażyna Hoser ${ }^{3}$, Jacek Tabarkiewicz ${ }^{2}$, \\ Sebastian Radej², Anna Dmoszynska ${ }^{1}$, Jacek Rolinski ${ }^{2}$ \\ ${ }^{1}$ Department of Hematooncology and Bone Marrow Transplantation, Medical University of Lublin, \\ Poland \\ ${ }^{2}$ Department of Clinical Immunology, Medical University of Lublin, Poland, \\ ${ }^{3}$ Clinical Cytology Department, Medical Centre of Postgraduate Education, Warsaw, Poland
}

\begin{abstract}
In the present study we investigated in vivo therapeutic potential of DCs vaccines in B-cell chronic lymphocytic leukemia (B-CLL). On the day 0 the SCID mice were intraperitoneally inoculated with peripheral blood mononuclear cells (PBMC) of B-CLL patients at a dose of 10-30 $\times 10^{6}$ and left untreated (controls) or i.p. injected on the day 7 with 0.2 $-14.0 \times 10^{6}$ dendritic cells. DCs were generated in vitro from peripheral blood monocytes of B-CLL donors (autologous DCs) or healthy donors (allogeneic cells) and pulsed with B-CLL antigens. On the day 14, the effect of implanted cells interactions was evaluated by a counting of CD19+CD5+ human leukemic cells and human T cells in the peritoneal fluid of mice. We found, that mean numbers of CD19+CD5+ leukemic cells as well as human T cells were lowered in peritoneal fluid of mice treated with allogeneic APCs.. However, we did not observe similar effects with autologous DCs.
\end{abstract}

Key words: B-cell chronic lymphocytic leukemia, SCID mice, autologous and allogeneic dendritic cells

\section{Introduction}

B-cell chronic lymphocytic leukemia (B-CLL) is a most frequent type of leukemia of adults in Western world [1]. Since it is a slow growing malignancy, the time allows for an immunotherapy attempts against the tumor cells to be generated by vaccination $[2,3]$. It is easy to obtain tumor cells for vaccine production, as the leukemia cells circulate in large amounts in peripheral blood. The positive clinical observations in patients vaccinated with the irradiated autologous leukemia cells could be explained by hypothesis of dendritic cells (DC) activity [4,5]. DCs are the most potent cancer antigen's presenting cells that initiate effective T-cell response [6,7] observed as the result of these vaccinations. The active DCs have been shown in clinical observations of melanoma and prostate carcinoma $[8,9,10]$. They have also been used with some

Correspondence: J. Kawiak, MD, PhD, Clinical Cytology

Department, Medical Centre of Postgraduate Education,

Marymoncka 99, 01-813 Warsaw, Poland;

tel: +48 0225693 830, e-mail: jkawiak@cmkp.edu.pl success to generate an immune response against idiotype peptides in patients with follicular B-cell lymphoma [11]. It has been shown that functional DCs can be generated from peripheral blood monocytes of BCLL patients in early stages of the disease $[12,13]$. The DCs stimulated with tumor antigens from leukemic cell lysates or apoptotic bodies induced in vitro strong response of specific cytotoxic T lymphocytes (CTLs) $[14,15]$.

Several problems of DCs activity are unknown, and may be asked in model experiments. SCID (severe combined immunodeficiency) mice have been proved a useful model for studies of autoimmune diseases as well as cancer diseases, including B-CLL $[16,17]$. We established a SCID mouse xenotransplant model to study the effect of DCs on human BCLL cells counts [18]. In the present study, we implanted leukemic cells into peritoneal cavity of SCID mice, then the animals received human autologous or allogeneic monocytederived DCs pulsed with tumor cell lysates or irradiat-

\footnotetext{
*equal contribution of both authors
} 
Table 1. Clinical and laboratory characteristics of B-CLL patients, whose cells were implanted into SCID mice. Normal range of WBC/lymphocytes: 4-10/0.8-4.3(G/1). 2-M 0.8-2.2mg/L; abnormal values are marked with asterisk for ZAP-70, CD38, 2-M; stages according to Rai [23]; clinical response for autoDC vaccines (see results): RS - response, SD - stable disease, NR - no response; Abbreviations: $\mathrm{N}$ - normal; ND - not done, NT - not treated.

\begin{tabular}{|c|c|c|c|c|c|c|c|c|}
\hline Paticnt & $\begin{array}{c}\Lambda \text { ge/ } \\
\text { scx }\end{array}$ & $\begin{array}{c}\text { Stage acc } \\
\text { Rai }\end{array}$ & $\begin{array}{c}\text { WBC/ } \\
\text { lymphocyles } \\
(\mathrm{G} / \mathrm{l})\end{array}$ & $\begin{array}{c}\text { Lymph } \\
\text { nodes/ } \\
\text { spleen }(\mathrm{cm})\end{array}$ & $\begin{array}{c}7 . \Lambda \mathrm{P}-70 \\
(\%)\end{array}$ & $\begin{array}{c}\mathrm{CD} 38 \\
(\%)\end{array}$ & $\begin{array}{c}\beta 2-\mathrm{M} \\
(\mathrm{mg} / \mathrm{L} .)\end{array}$ & $\begin{array}{c}\text { Clinical response for } \\
\text { autol)C vaccincs }\end{array}$ \\
\hline$\# 1$ & $54 / \mathrm{M}$ & 2 & $35.6 / 28.4$ & $\mathrm{~N}$ & 10.93 & 9.56 & 2.09 & $\mathrm{NR}$ \\
\hline$\# 2$ & $59 / \mathrm{F}$ & 0 & $15.9 / 8.9$ & $\mathrm{~N}$ & 14.52 & 9.56 & $2.41^{*}$ & $\mathrm{RS}$ \\
\hline$\# 4$ & $57 / \mathrm{M}$ & 1 & $19.8 / 10.7$ & 1.0 & 14.43 & $63.1^{*}$ & 1.15 & $\mathrm{SD}$ \\
\hline$\# 5$ & $67 / \mathrm{F}$ & 0 & $35.9 / 28.1$ & $\mathrm{~N}$ & $20.45^{*}$ & 1.69 & 2.13 & $\mathrm{SD}$ \\
\hline$\# 6$ & $67 / \mathrm{M}$ & 0 & $28.3 / 22.9$ & $\mathrm{~N}$ & $22.37^{*}$ & 16.06 & 1.99 & $\mathrm{SD}$ \\
\hline$\# 7$ & $47 / \mathrm{M}$ & 2 & $18.5 / 13.5$ & $1.0 / 12.1$ & $54.27^{*}$ & $73.98^{*}$ & $\mathrm{ND}$ & $\mathrm{SD}$ \\
\hline$\# 8$ & $61 / \mathrm{F}$ & 0 & $30.4 / 19.1$ & $\mathrm{~N}$ & 15.94 & 4.82 & $2.78^{*}$ & $\mathrm{SD}$ \\
\hline$\# 9$ & $69 / \mathrm{M}$ & 0 & $21.5 / 15.4$ & $\mathrm{~N}$ & $28.95^{*}$ & $45.95^{*}$ & $2.50^{*}$ & $\mathrm{SD}$ \\
\hline$\# 10$ & $57 / \mathrm{M}$ & 0 & $26.2 / 19.4$ & $\mathrm{~N}$ & 16.3 & 7.54 & 1.87 & $\mathrm{NT}$ \\
\hline
\end{tabular}

Normal range of WBC/lymphocytes: 4-10/0.8-4.3(G/1). $\beta 2-\mathrm{M} \quad 0.8-2.2 \mathrm{mg} / \mathrm{L}$; abnormal values are marked with asterisk for ZAP-70, CD38, $\beta 2-\mathrm{M}$; stages according to Rai [23]; clinical response for autoDC vaccines (see results): RS - response, SD - stable disease, NR - no response; Abbreviations: N - normal; ND - not done, NT - not treated;

ed leukemia cells in order to compare in vivo therapeutic potential of both DCs vaccines in B-CLL.

\section{Materials and methods}

Mice. The pathogen-free, 10-12 weeks-old severe combined immunodeficient (SCID) mice (BALB/c C.B-17/IcrHanHsd-scid [19] were our own breeding; first families were from Harlan Shaw's Farm, UK. The animals were housed in sterilized microisolator cages and received vitamins, autoclaved food and drinking water. The mice were systematically controlled for the absence of peripheral blood $\mathrm{B}$ and $\mathrm{T}$ lymphocytes with antimouse CD19 PE (clone ID3) and anti-mouse CD3 FITC (clone 17A2), (Pharmingen).

Before the implantation of human cells the animals were immunosupressed by s.c. injection of cyclofosfamide, $3 \mathrm{mg} / \mathrm{animal}$ on the day 3 and the day 2 before inoculation of the human cells $[20,21]$. Then the animals were treated every $2-3$ days s.c. with hybridoma PK136 cells culture supernatant containing the antiNK1.1 monoclonal antibodies (4 $\mu \mathrm{g} \operatorname{IgG})$ to suppress mice NK cells activity [22]. The experiment protocol was accepted by Local Ethic Commision for Animal Experiments (Nr KE 271/2003).

Cell donors: leukemic patients and healthy donors. B-cells for implantation were obtained from untreated patients in 0-2 stage according to Rai [23] (Table 1). The peripheral blood samples (20 $\mathrm{ml}$ ) were collected on heparin after informed consent obtained from the patient in accordance with the Declaration of Helsinki and with the approval by the Local Ethics Committee of the Medical University at Lublin (KE-0254/239/2002). The peripheral blood samples $(40 \mathrm{ml})$ from patients and healthy donors for preparation of dendritic cells were collected similarly.

Preparation of cells for implantation. Leukemia B-CLL cells were present in mononuclear fraction obtained by the Lymphoprep (Nycomede, Oslo, Norway) density gradient centrifugation for 20 min at 200xg. The number of mononuclear living cells was counted in propidium iodide cytometric test [24]. Monoclonal antibodies to antigens present on human lymphocytes, all from Becton Dickinson, were used to evaluate the number of HLAABC positive cells (clone G46-2.6), CD45+ cells (clone 2D1, IgG1), B-cells CD19+ (clone 4G7, IgG1), leukemia B-cells CD5+/CD19+ (clones $\mathrm{L} 17 \mathrm{~F} 12 / \mathrm{SJ} 25 \mathrm{C} 1$, IgG2a/IgG1), and normal CD3+ T lymphocytes (clone SK7, IgG1) with the cytometer. The isotype control antobodies were applied as well.

Implantation of B-CLL and dendritic cells. The patient peripheral blood mononuclear cells, $12-25 \times 10^{6} /$ animal containing known number of leukemia B-cells and $\mathrm{T}$ cells were implanted intraperitoneally (ip) at day zero. The 13 out of 27 B-CLL xenografted mice served as controls and investigated 14 days later while the 14 of them were implanted on the day 7 with human cell suspension containing the DCs prepared as described below and investigated 7 days later.

Generation of autologous and allogeneic DCs. Dendritic cells were generated from peripheral blood monocytes according to previously described procedures [13]. Briefly, mononuclear cells isolated from $40 \mathrm{~mL}$ of peripheral blood taken from patients with BCLL and healthy donors were used. Cells were allowed to adhere to plastic dishes for $90 \mathrm{~min}$. at $37^{\circ} \mathrm{C}$. Thereafter the adherent fraction of PBMC was cultured in a medium containing RPMI-1640 supplemented with $2 \%$ human albumin (ZLB Bioplasma AG, Bern, Switzerland), penicillin $100 \mathrm{IU} / \mathrm{ml}$, streptomycin $50 \mathrm{mg} / \mathrm{ml}$, neomycin $100 \mathrm{mg} / \mathrm{ml}$ ). On day 1,3 and 5 of the culture, 1.000 $\mathrm{IU} / \mathrm{ml}$ rhGM-CSF (Leucomax, Novartis, Basel, Switzerland) and $500 \mathrm{ng} / \mathrm{ml} \mathrm{rhIL}-4$ (Strathmann, Hannover, Germany) were added to the culture medium. On day 6, the lysates of $7 \times 107$ autologous leukemic B-cells were used for the pulsing of the DCs. On day seven, $50 \mathrm{ng} / \mathrm{ml} \mathrm{rhTNF}-\alpha$ was added to the culture and the cells were stimulated for $2 \mathrm{~h}$. Thereafter cells were collected, washed twice in $0.9 \% \mathrm{NaCl}$ and resuspended in $0.5-1.0 \mathrm{~mL}$ of $0.9 \% \mathrm{NaCl}$. Before implantation, the suspension of DCs cell populations were analyzed as described for PBMC, and finaly DCs at a dose: DCauto 0.5 to $14 \times 10^{6}$, while DCallo 0.2 to $2 \times 10^{6}$ cells per mouse were injected intraperitoneally. Characterization of the dendritic cells suspensions are in Table 2 (see results).

Analysis of B-CLL counts after autologous and allogeneic DCs implantation. At day 14 from implantation of PBMC, and 7 from implantation of DCs, the number of leukemia cells in peritoneal cav- 
Table 2. Characterization of lymphocytes implanted ip to the mice with DCauto and DCallo. $\mathrm{M}=$ median values $(\mathrm{P} 25-\mathrm{P} 75)=25$ and 75 percentile values.

\begin{tabular}{|l|c|c|c|c|}
\hline \multicolumn{1}{|c|}{ DC } & I, $\%$ & CD19\% & CD5+/CD19+ & CD3\% \\
\hline DCauto, $\mathrm{n}=5$ & 82 & 92 & 79 & 5 \\
Median, (P25-P75) & $(56-91)$ & $(73-92)$ & $(54-83)$ & $(3-6)$ \\
\hline DCallo, n=6 & 68 & 59 & 4 & 14 \\
Median, (P25-P75) & $(55-87)$ & $(49-65)$ & $(2-26)^{*}$ & $(11-30)$ \\
\hline
\end{tabular}

*some CD5+/CD19+ auto "apoptotic bodies" may be present

ity of the animal was analyzed. First the animal was sacrified, then the peritoneal cavity was washed out with $2 \mathrm{ml}$ of the sterile physiological salt solution and cells were analyzed in that suspension.

Flow cytometry and statistics. The number of peritoneal cavity cells was counted and the number of human populations CD45+, CD5+/CD19+, and CD3+ per animal were analyzed as described above for cells before implantation. Cross-reaction of the antihuman leukocyte antibodies with mice leukocytes was not observed. The cells were analyzed by flow cytometry (Becton Dickinson FACSCalibur) in CellQuest application (3.2.1f1). Nonparametric statistics was used. The median value and percentile values (P25 and P75) were calculated for results of experiments and the statistically significant difference of results was assumed for $\mathrm{p}<0.05$ in Mann-Whitney U-test.

\section{Results}

The characteristics of chronic B-lymphocytic leukemia patients participating in experiments with DC are summarized in Table 1. All patients, 47-69 years old, were diagnosed with B-CLL in early stages (Rai 0-2), according to NCI (National Cancer Institute) criteria, and were previously untreated. The results of peripheral blood leukocytes and laboratory tests of patients including analyzes of leukemia cells ZAP-70 and CD38 were assayed.

The patients were treated later clinically with autological DCs vaccines and the clinical result of treatment is included in the Table 1. The patients who showed a $25 \%$ or higher reduction in their WBC count after vaccination were considered responders (RS), patients with less than $25 \%$ reduction - stable disease (SD), and patients with an increase of their WBC - non responders (NR). Most patients responded for the DCs vaccines with stable disease (SD).

\section{Evaluation of conditions for the experiment}

In the initial part of the study [18], mouse xenotransplant model was established. For this, SCID mice were inoculated with B-CLL patients' PBMC at different doses ranging from 10.0 to $150.0 \times 10^{6}$ cells per mouse. The optimal range of implanted PBMC was established for 10-30 × 106/animal, as used in the present experiments. It was observed, that ip implanted hemopoietic cells remain locally and are not distributed significantly to the spleen, bone marrow or peripheral blood of the mouse [18] (Fig.1D). Consequently, here we analyzed only cells present in the peritoneal cavity of the animals. The experiments were not prolonged to 21 days from PBMC implantation because it was observed, that the number of cells is significantly decreased between 14 to 21 days.

With ip implants mice received patients mononuclear cells at the Median dose $15.5 \times 10^{6}$ containing about $96 \%$ of living, CD $45+$ hematopoietic cells. With implantation of dendritic cells, mice received additional portion of human hemopoietic cells which rised the number of CD45+ cells on $10 \%$ with autologous DC, or $0.4 \%$ with allogeneic DC.

Characterization of the lymphocytes implanted with the suspension of dendritic cells is presented in Table 2. With allogeneic DCs the allogeneic T lymphocytes were applied.

The animals with implanted B-CLL cells appeared healthy within the period of experiment. The number of B-CLL cells and T lymphocytes implanted was a sum of the cells given at day zero and the cells added at day 7 with suspension of DC. The final analysis was at day 14 from implantation of human leukemia cells and it appeared, that from implanted cells, only $0.23 \times$ $10^{6}$ were recoverd $(1.7 \%)$ at analysis (Table 3 ). In two experiments, the immunosupression with monoclonal anti-NK1.1 only was attempted, but the suppression was uncomplete and these results were not included in the final analysis.

\section{Cell populations in control animals}

The number of human cell populations from different patients in control animals is presented in Table 4. The recovered number of human subpopulations of hemopoietic CD45+ cells is the sum of leukemia B cells CD19+/CD5+ $\left(333 \times 10^{3}\right)$, normal T CD3+ cells $\left(17 \times 10^{3}\right)$, and probably normal B cells (Fig.1A,B, C). The presence of $\mathrm{T}$ cells subpopulation is important for possible interaction with DCs in process of crosspresentation and stimulation of $\mathrm{T}$ cells response. In some experiments human HLAABC positive cells were tested and were observed (not presented in details). 
Table 3. Number of implanted patients peripheral blood MNC and recovered human hematopoietic cells CD45+ . M = median values $(\mathrm{P} 25-\mathrm{P} 75)=25$ and 75 percentile values.

\begin{tabular}{|l|c|c|c|}
\hline \multicolumn{1}{|c|}{ Patient } & $\begin{array}{c}\text { Cells implanted, } \\
\text { Day 0 }\left(\times 10^{3}\right)\end{array}$ & $\begin{array}{c}\text { Cells cd45+ recovered*; } \\
\text { Day 14 }\left(\times 10^{3}\right)\end{array}$ & $\begin{array}{c}\text { \% of cells } \\
\text { Recovered }\end{array}$ \\
\hline$\# 1$ & 12000 & 187 & 1.56 \\
\hline$\#$ 2, analysis at day 9th & 6000 & day 9 3500 & - \\
\hline$\# 4$ & 17000 & 124 & 0.73 \\
\hline$\# 5$ & 25000 & 2862 & 2.90 \\
\hline$\# 6$ & 25000 & 724 & 1.45 \\
\hline$\# 6 a$ & 14000 & 170 & 3.32 \\
\hline$\# 7$ & 12000 & 398 & 1.83 \\
\hline$\# 8$ & 14000 & 256 & 0.84 \\
\hline$\# 9$ & 25000 & 209 & $1.70(1.03-3.11)$ \\
\hline Median (P25-P75) & $15500(12000-25000)$ & $226(179-561)$ & \\
\hline
\end{tabular}

*mean from 2-6 animals from the same patient; patient \#6 was the donor for two experiments; patient \#2 was excluded from calculations as the result was analyzed at day 9 th

\section{Autologous or allogeneic DCs interaction with lymphocytes}

Results in control animals with implanted patient's leukemia B-CLL cells without DC were compared with that from animals with B-CLL cells from the same patient that additionally have implanted auto-DC or allo-DC activated with the same patient's leukemia cells lysate and TNF. At the day 7 from implantation of allogeneic DC to animals, the CD45+ hemopoietic cells and leukemia B cells CD5+/CD19+ populations were significantly lower as compared with the control animals (Table 5). The number of cells in the populations CD19+ B cells and CD3+ T cells had a tendency to decrease. The result may be interpreted as in vivo
A

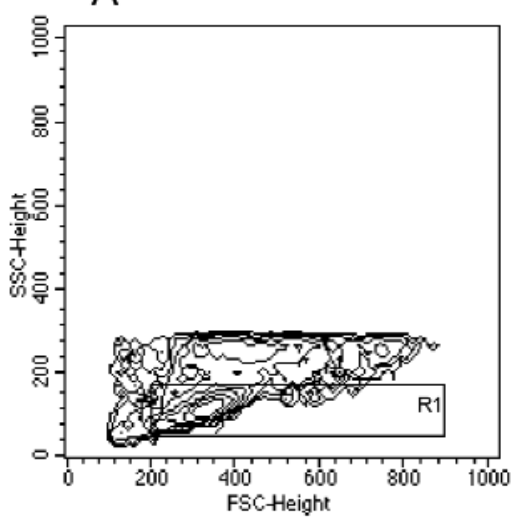

C

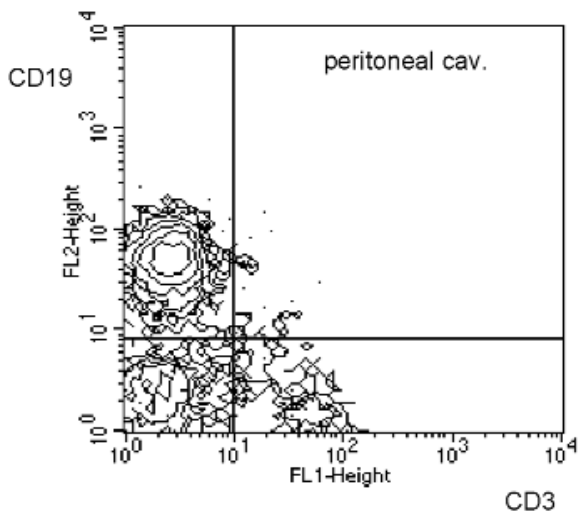

B
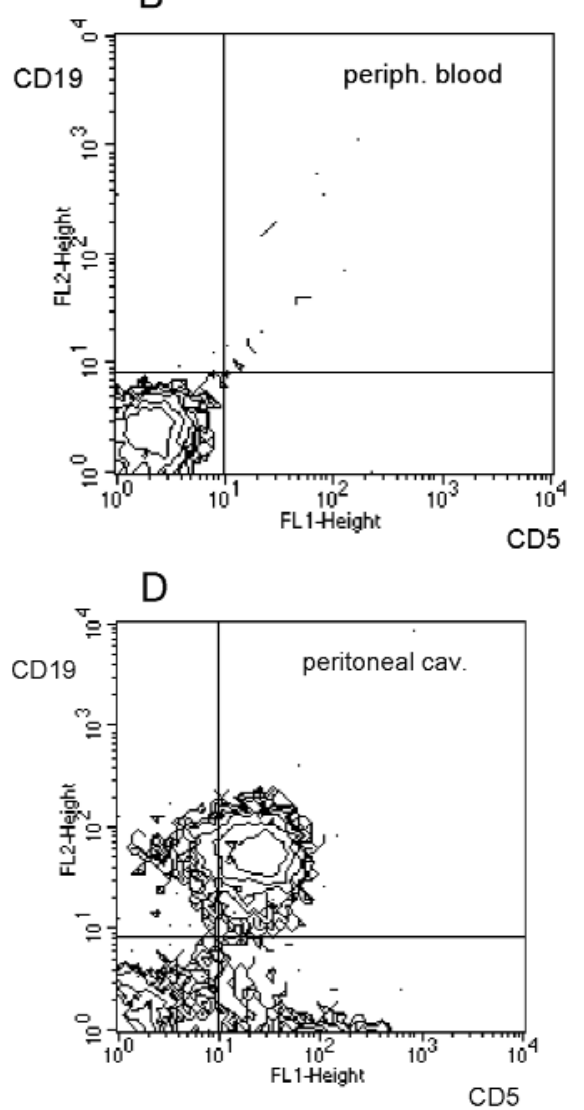

Fig. 1. Cytometric assay of human lymphocytes washed out from the peritoneal cavity $(1 \mathrm{~A}, 1 \mathrm{C}, 1 \mathrm{D})$ or from the peripheral blood (1B) of the animal analyzed 14 days after implantation of B-CLL cells of the patient. Lymphocytes B CD19+ and lymphocytes T $\mathrm{CD} 3+(1 \mathrm{C})$ as well as leukemia cells CD19+CD5+ (1B, 1D) may be recognized. Note, the high number of leukemia cells in the peritoneum (1D) and traces of leukemia cells in the peripheral blood (1B) of the same animal. FSC/SSC gate for mouse and human lymphocytes is at Fig.1A. 
Table 4. The analysis of human cells populations in peritoneal cavity of particular 27 SCID mice at day 14 after ip inoculation with peripheral blood mononuclear cells of B-CLL patients without (control) or with post-injection (on day 7) with human allogeneic or autologous dendritic cells (DCallo, DCauto, respectively). $\mathrm{M}=$ median value, $(\mathrm{P} 25-\mathrm{P} 75)=25$ and 75 percentile values.

\begin{tabular}{|c|c|c|c|c|c|c|}
\hline $\begin{array}{l}\text { Patient, } \\
\text { Mouse, DC }\end{array}$ & $\begin{array}{l}\text { Cells recoved } \\
\times 10^{3}\end{array}$ & $\begin{array}{l}\text { L-gate cells } \\
\mathrm{X} 10^{3}\end{array}$ & $\begin{array}{c}\mathrm{CD} 45+ \\
\text { Cells } \\
\mathrm{X} 10^{3}\end{array}$ & $\begin{array}{c}\mathrm{CD} 19+ \\
\text { Cells } \\
\mathrm{X} 10^{3}\end{array}$ & $\begin{array}{c}\mathrm{CD} 5+/ 19+ \\
\text { Cells } \\
\mathrm{X} 10^{3}\end{array}$ & $\begin{array}{l}\mathrm{CD} 3+, \\
\text { Cells } \\
\mathrm{X} 10^{3}\end{array}$ \\
\hline$\# 1$, control $1 \mathrm{~m}$ & 2700 & 928 & $\mathrm{ND}$ & 393 & 333 & 3 \\
\hline$\# 1$, control $2 \mathrm{~m}$ & 1900 & 582 & $\mathrm{ND}$ & 112 & 105 & 1 \\
\hline$\# 4$, control $1 \mathrm{~m}$ & 300 & 259 & 185 & 6 & 6 & 132 \\
\hline$\# 5$, control $1 \mathrm{~m}$ & 3000 & 2037 & 1686 & 573 & 572 & 1400 \\
\hline$\# 5$, control $2 \mathrm{~m}$ & 8100 & 4763 & 4294 & 2194 & 2975 & 1397 \\
\hline$\# 6$, control $1 \mathrm{~m}$ & 7600 & 727 & 430 & 456 & 449 & 16 \\
\hline$\# 6 \mathrm{a}$, control 1m & 2400 & 932 & 473 & 493 & 535 & 19 \\
\hline$\# 7$, control $1 \mathrm{~m}$ & 1200 & 483 & 320 & 313 & 308 & 6 \\
\hline$\# 7$, control $2 \mathrm{~m}$ & 1400 & 536 & 443 & 431 & 431 & 16 \\
\hline$\# 8$, control lm & 1000 & $\mathrm{ND}$ & 597 & 739 & 1027 & 17 \\
\hline$\# 8$, control $2 \mathrm{~m}$ & 1600 & 718 & 224 & 306 & 270 & 5 \\
\hline$\# 9$, control $1 \mathrm{~m}$ & 1000 & 585 & 98 & 33 & 34 & 63 \\
\hline$\# 9$, control $2 \mathrm{~m}$ & 2200 & 1168 & 323 & 202 & 262 & 107 \\
\hline \#1,1m,DCallo & 2700 & 753 & ND & 129 & 105 & 1 \\
\hline$\# 4,1 \mathrm{~m}, \mathrm{DC}$ Callo & 800 & 631 & 63 & 44 & 57 & 8 \\
\hline \#6a, lm, LCallo & 3440 & 819 & 24 & 16 & 18 & 4 \\
\hline \#6a,2m,DCallo & 3260 & 1050 & 178 & 196 & 226 & 7 \\
\hline \#1,1m,DCauto & 1100 & 382 & $\mathrm{ND}$ & 106 & 87 & 1 \\
\hline$\# 4,1 \mathrm{~m}$,DCauto & 400 & 265 & 124 & 11 & 9 & 84 \\
\hline \#5,1m,DCauto & 4400 & 2193 & 1804 & 1270 & 1310 & 364 \\
\hline$\# 5,2 \mathrm{~m}, \mathrm{DC}$ Cauto & 6400 & 4177 & 3663 & 2830 & 2620 & 627 \\
\hline \#7,1m,DCauto & 1300 & 820 & 313 & 308 & 299 & 2 \\
\hline \#7,2m,DCauto & 1500 & 677 & 496 & 466 & 450 & 37 \\
\hline \#8,1m,DCauto & 1800 & 769 & 163 & 137 & 138 & 6 \\
\hline$\# 8,2 \mathrm{~m}$,DCauto & 2400 & 677 & 49 & 40 & 43 & 2 \\
\hline$\# 9,1 \mathrm{~m}$, DCauto & 1600 & 1007 & 301 & 318 & 327 & 21 \\
\hline$\# 9,2 \mathrm{~m}$, DCauto & 800 & 372 & 115 & 83 & 64 & 96 \\
\hline
\end{tabular}

MLC (mixed lymphocyte culture) interaction between patient's lymphocytes and T cells of donor DCs, something like acute graft versus host $(\mathrm{GVH})$ response. It is not the result of activating interaction between allogeneic DCs and patients T lymphocytes, because the number of $\mathrm{T}$ cells is decreasing similarly as the number of leukemia cells.

There were no significant differences in the counts of cell populations CD45+, CD19+, CD5+/CD19+ in animals treated with autologous DC cells as compared to the control animals. However, there is a tendency of $\mathrm{CD} 3+\mathrm{T}$ cells number to increase, nearly three times, from $17 \times 10^{3}$ /animal in controls to $48 \times 10^{3}$ /animal in DCs implanted, a possible result of DC autologous and
$\mathrm{T}$ cells activating interaction, and proliferation of $\mathrm{T}$ cells. Results are presented in Table 5.

\section{Discussion}

Despite the results of in vitro studies showing that functional DCs can be generated from peripheral blood monocytes of patients with B-CLL [14], and the specific CTL against B-CLL cells could be achieved using DCs pulsed with leukemic antigens [25], so far, there was only one reported clinical trial on DCs immunotherapy in B-CLL [13]. Therefore, we have established a SCID mouse model to study in vivo, the effect of DCs vaccinations on the number of B-CLL 
Table 5. Effect of human allogeneic dendritic cells (DCallo) or autogeneic dendritic cells (DCauto) implantation on the number of human cell populations washed out from SCID mouse peritoneal cavity in comparison with that in control SCID mice injected with leukemic cells only. $\mathrm{M}=$ median values, $(\mathrm{P} 25-75)=25$ and 75 percentile values. $\mathrm{p}=$ significance of difference between human cell populations in control animals; $\mathrm{p}<0.05$ assumed as significant.

\begin{tabular}{|c|c|c|c|c|c|c|}
\hline $\begin{array}{l}\text { Patient, } \\
\text { mouse,DC }\end{array}$ & $\begin{array}{l}\text { Cells recoved } \\
\quad \times 10^{3}\end{array}$ & $\begin{array}{c}\text { L-gate cells } \\
\times 10^{3}\end{array}$ & $\begin{array}{l}\mathrm{CD} 45+, \\
\text { cells } \\
\times 10^{3}\end{array}$ & $\begin{array}{l}\text { CD19+, } \\
\text { cells } \\
\text { x10 }\end{array}$ & $\begin{array}{c}\text { CD } 5+/ 19+ \\
\text { cells } \\
\times 10^{3}\end{array}$ & $\begin{array}{l}\mathrm{CD} 3+ \\
\text { cells } \\
\times 10^{3}\end{array}$ \\
\hline $\begin{array}{c}\text { control, } \\
\text { M, (P25-P75) } \\
\text { n=11-13 }\end{array}$ & $\begin{array}{c}1900 \\
(1150-2775) \\
n=13\end{array}$ & $\begin{array}{c}723 \\
(559-1050) \\
n=12\end{array}$ & $\begin{array}{c}443 \\
(248-566) \\
n=11\end{array}$ & $\begin{array}{c}393 \\
(180-513) \\
n=13\end{array}$ & $\begin{array}{c}333 \\
(223-544) \\
n=13\end{array}$ & $\begin{array}{c}17 \\
(6-113) \\
n=13\end{array}$ \\
\hline $\begin{array}{c}\text { DCallo, } \\
\text { M, (P25-P75) } \\
\text { n=4 }\end{array}$ & $\begin{array}{c}2980 \\
(1750-3350)\end{array}$ & $\begin{array}{c}786 \\
(692-935)\end{array}$ & $\begin{array}{c}63 \\
(34-149)\end{array}$ & $\begin{array}{c}87 \\
(30-163)\end{array}$ & $\begin{array}{c}81 \\
(38-166)\end{array}$ & $\begin{array}{c}6 \\
(2.5-7.5)\end{array}$ \\
\hline $\mathrm{p}$ & & & 0.0158 & 0.0542 & 0.0474 & 0.0789 \\
\hline $\begin{array}{c}\text { DCauto, } \\
\text { M, (P25-P75) } \\
\text { n=10 }\end{array}$ & $\begin{array}{c}1700 \\
(1100-2400)\end{array}$ & $\begin{array}{c}795 \\
(382-1007)\end{array}$ & $\begin{array}{c}355 \\
(122-823)\end{array}$ & $\begin{array}{c}313 \\
(83-466)\end{array}$ & $\begin{array}{c}345 \\
(64-450)\end{array}$ & $\begin{array}{c}48 \\
(2-96)\end{array}$ \\
\hline $\mathrm{p}$ & & & 0.3423 & 0.3226 & 0.4951 & 0.8523 \\
\hline
\end{tabular}

cells. In the initial part of experiment [18] we transplanted different doses of PBMC isolated from patients with B-CLL with an intend to evaluate the distribution as well as the count of leukemic cells in different tissues, such as peripheral blood, bone marrow, peritoneal cavity, spleen and liver. We found, that high number of inoculated cells $\left(150.0 \times 10^{6}\right)$ induced death of animals [18], and if the number of implanted PBMC did not exceed 50.0-90.0 × 106/per mouse, leukemic cells were eliminated within 60 days. Similar observations, concerning correlations between survival time and a number of implanted B-CLL cell line were reported by Kawata et al. [26]. We have also found individual differences in the survival time between animals transplanted with similar dose of cells from different patients, resulting probably from different activity and proliferative potential of leukemic cells in individual patients, as well as from heterogeneic clinical course of B-CLL. In the other study survival time of SCID mice inoculated with T-CLL cells at a dose $40.0 \times 10^{6}$ ranged from 43 to 69 days [27]. In our study, even higher dose was eliminated from mice that may result from more aggressive character of T-CLL comparing to B-CLL.

After intraperitoneal implantation of PBMC isolated from patients with B-CLL, CD19+CD5+ cells were found at 14 days in small number in peripheral blood, bone marrow, and spleen of mice as compared to peritoneal cavity [18]. In the study of Hummel et al. [17], after intravenous injection of PBMC obtained from BCLL patients, leukemic cells were found the most often in the spleen, lungs, bone marrow and kidneys.

Thus, distribution of leukemic cells in mice may depend on the route of injection, and the different chemokines secreted by spleen and bone marrow stro- mal cells [28]. The stromal cells of mice peritoneum are known from secretion of SDF-1 chemokine $[29,30]$, and leukemia B-CLL cells express the CXCR4 receptor. That may, at least partly, explain homing of leukemia cells at peritoneal site of implantation.

Gradual elimination of leukemic cells from SCID mice organisms observed in our study was probably the effect of residual activity of immune system. Even so, there are no active B or T cells in SCID mice [19], increased activity of NK cells as well as normal function of granulocytes and macrophages was reported. That is why, before implantation of human peripheral blood cells, mice were treated with cyclophosphamide in order to suppress residual activity of their own immune system. Immunosuppressive effect of cyclophosphamide lasts for about 2 weeks and this restricted time of our observations to 14 days.

The main problem with B-CLL studies on SCID mouse model is, that high dose of implanted human leukemia cells instead of long lasting chronic stage of B-CLL form, induce rapid death of animals due to secondary tumours. It was found, that the reason was the latent form of Epstein-Barr virus (EBV) present in mice organisms, that activated under immunosuppressive conditions transformation of B-CLL lymphocytes in aggressive lymphoma cells causing the death of mice within 8-16 weeks [31]. According Kobayashi et al. [32] aggressive B-cell lymphomas, causing the death of animals in short time after B-CLL cells transplantation, origin not from leukemic cells, but from bystander B cells infected with EBV. In our study, the evaluation of human DCs effect was studied within two weeks after B-CLL cells implantation, so previous to both elimination of inoculated cells, as well as 
prospective development of aggressive B-cell lymphomas connected with EBV infection.

We observed, that the number of B-CLL cells in peritoneal fluid was lower in mice treated with allogeneic DCs, comparing to the mice that received only leukemic cells. In this system we observed acute graft versus host $(\mathrm{GVH})$ response between human allogeneic implanted cells within the mouse peritoneal cavity. This is suggested by the parallel decrease of human BCLL and T cells, as allogeneic DCs presentation of leukemia antigens would activate $\mathrm{T}$ cells for proliferation rather, and not the observed $\mathrm{T}$ cells killing.

The observed unresponsiveness of patients own $T$ lymphocytes to autologous dendritic cells may be partly explained by B-CLL patient's DCs defective phagocytosis recently recorded [3]. We observed, that the vaccination of patients with the irradiated leukemia cells improve of DCs phagocytotic activity. The autologous DCs applied in the present SCID mouse experiment were from patients before vaccination. However, the observed number of T cells at time of analysis was already nearly 3-times higher in animals treated with autologous DCs as compared to control animals. The result suggests crosspresentation of leukemia antigens by DCs to autologous $\mathrm{T}$ cells inducing proliferation of these cells.

In conclusion, in the present study we established a model of B-CLL cells implantation into SCID mice, than on this model the in vivo effects of DCs immunotherapy were evaluated. In experimental model, we found tendency to rise of human $\mathrm{T}$ cells in animals treated with autologous DCs that were from unvaccinated B-CLL patients. These observation confirm deficiency of DCs in the unvaccinated patients recently recorded.

The result of experiment with allogeneic DCs resemble acute GVH response. However, the correlation between clinical response and experimental data from mice model remains equivocal and requires further studies. It seems worth to continue the presented studies on SCID mouse model in order to improve the efficacy of DCs immunotherapy in B-CLL patients.

Acknowledgements: This study was supported by State Committee for Scientific Research, grant: No. 2 PO5B 63630 and Medical Centre of Postgraduate Education, grants for 2006/2007.

\section{References}

[ 1] Rozman C, Montserrat E: Chronic lymphocytic leukemia. $N$ Engl J Med. 1995;333:1052-1057.

[ 2] Le Dieu R, Gribben J. Vaccine- and immune-based therapy in chronic lymphocytic leukemia. Semin Oncol. 2006;33:220229.

[ 3] Hus I, Kawiak J, Tabarkiewicz J, Radej S, Hoser G, BojarskaJunak A, Schmitt M, Giannopoulos K, Dmoszynska A, Rolinski J. Immunotherapy with irradiated autologous leukemic cells in patients with B-CLL in early stages. Oncology Reports. 2008;20:443-451.
[4] Steinman RM. The dendritic cell system and its role in immunogenicity. Ann Rev Immunol. 1991;9:271-296.

[5] Lanzavecchia A. Mechanisms of antigen uptake for presentation. Current Opinion in Immunol. 1996;8:348-354.

[6] Avigan D. Dendritic cells: development, function and potential use for cancer immunotherapy. Blood Rev. 1999;31:51-64.

[ 7] Young JW, Steinman RM. The hematopoietic development of dendritic cells: a distinct pathway for myeloid differentiation. Stem Cells. 1996;14:376-387.

[ 8] Palucka AK, Ueno H, Connolly J, Kerneis-Norvell F, Blanck JP, Johnston DA, Fay J, Banchereau J. Dendritic cells loaded with killed allogeneic melanoma cells can induce objective clinical responses and MART-1 specific CD8+ T-cell immunity. J Immunother. 2006;29:545-557.

[9] Engell-Noerregaard L, Hansen TH, Andersen MH, Thor Straten P, Svane IM. Review of clinical studies on dendritic cell-based vaccination of patients with malignant melanoma: assessment of correlation between clinical response and vaccine parameters. Cancer Immunol Immunother. 2009;58:1-14.

[10] Small EJ, Schellhammer PF, Higano CS, Redfern CH, Nemunaitis JJ, Valone FH, Verjee SS, Jones LA, Hershberg RM. Placebo-controlled phase III trial of immunologic therapy with Sipuleucel-T (APC8015) in patients with metastatic, asymptomatic hormone refractory prostate cancer. $J$ Clin Oncol. 2008;24:3089-3094.

[11] Hsu FJ, Benike C, Fagnoni F. et al. Vaccination of patients with B-cell lymphoma using autologous antigen-pulsed dendritic cells. Nat Med. 1996;2:52-58.

[12] Vuillier F, Maloum K, Thomas EK, Jouanne C, Dighiero G, Scott-Algara D. Functional monocyte-derived dendritic cells can be generated in chronic lymphocytic leukaemia. $\mathrm{Br} J$ Haematol. 2001;115:831-844.

[13] Hus I, Schmitt M, Tabarkiewicz J, Radej S, Wojas K, Bojarska-Junak A, Schmitt A, Giannopoulos K, Dmoszynska A, Rolinski J. Vaccination of B-CLL patients with autologous dendritic cells can change the frequency of leukemia antigenspecific CD8+ T cells as well as CD4+CD25+FoxP3+ regulatory $\mathrm{T}$ cells toward an antileukemia response. Leukemia. 2008;22:1007-1017.

[14] Kokhaei P, Choudhury A, Mahdian R. et al. Apoptotic tumor cells are superior to tumor cell lysate, and tumor cell RNA in induction of autologous T cell response in B-CLL. Leukemia. 2004; 18:1810-1815.

[15] Goddard RV, Prentice AG, Copplestone JA, Kaminski ER. Generation in vitro of B-cell chronic lymphocytic leukaemia-proliferative and specific HLA class-II-restricted cytotoxic T-cell responses using autologous dendritic cells pulsed with tumour cell lysate. Clin Exp Immunol. 2001;126:16-28.

[16] Vormoor J, Lapidot T, Pflumio F, et al. Immature human cord blood progenitors engraft and proliferate to high levels in severe combined immunodeficient mice. Blood. 1994;83: 2489-2497.

[17] Hummel JL, Lichty BD, Reis M, Dube I, Kamel-Reid S. Engraftment of human chronic lymphocytic leukemia cells in SCID mice: in vivo and in vitro studies. Leukemia. 1996;10: 1370-1376.

[18] Hus I, Hoser G, Wasilewska D, Rolinski J, Tabarkiewicz J, Wojas K, Gorska M, Klepacz R, Kawiak J. Mouse xenotransplant model to study human B-CLL chronic lymphocytic leukemia. Polish J Environm Studies. 2005;14(suppl II):127131.

[19] Bosma GC, Custer RP, Bosma MJ. A severe combined immunodeficiency mutation in the mouse. Nature. 1983;301: 527-530.

[20] Skorski T, Nieborowska-Skorska M, Wlodarski P. et al. Treatment of Philadelphia leukemia in severe combined immunodeficient mice by combination of cyclophosphamide and 
bcr/abl antisense oligodeoxynucleotides. J Natl Cancer Inst. 1997;89:124-133.

[21] Basch RS, Quito FL, Beh J, Hirst JA. Growth of human hematopoietic cells in immunodeficient mice conditioned with cyclophosphamide and busulfan. Stem Cells. 1997;15: 314-323.

[22] Kulesza J, Hoser G, Wasilewska D, Kawiak J. NK cell depletion and recovery in SCID mice treated with anti-NK1.1 antibody. Folia Histochem Cytobiol. 2006;44:93-96.

[23] Rai KR, Sawitsky A, Cronkite EP, Chanana AD, Levy RN, Pasternack BS. Clinical staging of chronic lymphocytic leukemia. Blood. 1975;46:219-234.

[24] Darzynkiewicz Z, Li X, Gong J. Assays of cell viability: Discrimination of cells dying by apoptosis. In: Methods in Cell Biology, 41, Part A, p.15-38 Academic Press, SanDiego, New York, London 1994.

[25] Vuillier F, Maloum K, Thomas EK. et al. Idiotype-pulsed dendritic cells are able to induce antitumoral cytotoxic CD8 cells in chronic lymphocytic leukaemia. $\mathrm{Br} J$ Haematol. 2003;120:243-250.

[26] Kawata A, Han T, Dadey B. et al. Establishment and characterization of the tumors of chronic lymphocytic leukemia cell line in nude and SCID mice. Leuk Res. 1993;17:883-894.

[27] O'Brien S, Jeha S, Kantarjian H. et al. Engraftment of chronic prolymphocytic and T cell leukemia in SCID mice. Leukemia. 1996;10:338-344.
[28] Kucia M, Ratajczak J, Reca R, Janowska-Wieczorek A, Ratajczak MZ. Tissue-specific muscle, neural and liver stem/progenitor cells reside in the bone marrow, respond to an SDF-1 gradient and are mobilized into peripheral blood during stress and tissue injury. Blood Cells Mol Dis. 2004;32:52-57.

[29] Pinho Mde F, Hurtado SP, El-Cheikh MC et al. Haematopoietic progenitors in the adult mouse omentum: permanent production of B lymphocytes. Cell Tissue Res. 2005;319:91-102.

[30] Foussat A, Balabanian K, Amara A cow Production of SDF-1 by mesothelial cells and effects of this chemokine on peritoneal B lymphocytes. Eur J Immunol. 2001;31: 350-59.

[31] Rowe M, Young LS, Crocker J, Stokes H, Henderson S, Rickinson AB. Epstein-Barr virus (EBV)-associated lymphoproliferative disease in the SCID mouse model: implications for the pathogenesis of EBV-positive lymphomas in man. $J$ Exp Med. 1991;173:147-158.

[32] Kobayashi R, Picchio G, Kirven M. et al. Transfer of human chronic lymphocytic leukemia to mice with severe combined immune deficiency. Leuk Res. 1992;16:1013-1023.

Submitted: 3 July, 2009 Accepted after reviews: 19 October, 2009 